\title{
The Ninus Romance: New Textual and Contextual Studies
}

\author{
María Paz López Martínez*
}

\begin{abstract}
A new scenario is proposed regarding the origin of the Ninus: the text may have been written in Parthia halfway through the 1st century BC. This article offers a proposal for the plot of the first part of this work, and speculation on whether the motifs of the Ninus have left their mark on Persian literature. The existence of another Greek lost novel, where the main character would be Semiramis, is suggested.
\end{abstract}

Keywords: The Greek novel, Ninus, Semiramis, Parthia

https://doi.org/10.1515/apf-2019-0002

I. Introduction

II. The papyri and other materials related to the novel

III. The context of the novel's creation

IV. Date of writing and profile of the author

V. Plot of the first part of the novel

VI. Survival in the Persian tradition

VII. A different novel with Semiramis as its main character?

VIII. Conclusions

IX. Bibliography

Vorbemerkung: I greatly appreciate the valuable help given by Professor Fabian Reiter, Professor of Papyrology at the University of Bologna, regarding the papyrological questions addressed in the present paper. In addition, as so many other times in the past, the remarks and advice generously offered by Dr. Juan Luis López Cruces, Professor of Greek Studies at the University of Almería, have also proved extremely helpful for my work. In neither case does their help imply that they have any responsibility - this being mine alone-for possible errors or mistakes in the present paper.

'Kontakt: María Paz López Martínez, Departamento de Prehistoria, Arqueología, Historia Antigua, Filología Griega y Filología Latina, Universidad de Alicante, Carretera de San Vicente del Raspeig s/n, D.P. 03690 San Vicente del Raspeig, Alicante, Spain, <maripaz.lopez@ua.es> 


\section{Introduction}

Ninus is one of the first and most important representatives of the prose fiction genre. A singular artistic product, it narrates the vicissitudes in love and adventures of a young barbarian king set in a distant time and a context located far away from Greece: the Assyrian Empire. The literary level of the preserved fragments (described infra, section II) corresponds to educated rhetorical Greek littered with references to the previous tradition. We know for certain not only that it was read in Graeco-Roman Egypt from the 1 st century $\mathrm{BC}$ to the 1 st century $\mathrm{AD}$, but also that the work spread across the Empire's eastern provinces, especially Syria, in the 2nd and 3rd centuries AD.

The present study has a significant speculative component. Some new findings on the novel's context and the date it was written are discussed below, according to which Ninus would have been written in Parthia halfway through the 1 st century $\mathrm{BC}$. This hypothesis is supported by a review of the chronology of the preserved papyri and an ideological interpretation of the fragments, similar to that previously suggested with regard to other legendary figures who ruled ancient empires and were also main characters in fictional works, including the Egyptian pharaoh Sesonchosis or the Macedonian, Alexander the Great.

\section{Papyri and other materials related to the novel}

1. The remains of the original text comprise four fragments (henceforth $A$, B, C and D) from two different papyri. ${ }^{1}$ These are standard products, as revealed by the in-depth studies carried out by Cavallo (1996) and Del

\footnotetext{
${ }^{1}$ Fragments A and B belong to P Berol. 6926 (TM 63069, LDAB 4272, Mertens-Pack 2616); fragment C to P.Gen. II 85, and fragment D to PSI XIII.1305 (TM 63093, LDAB 4296, Mertens-Pack 02617.000). Editions by Kussl 1991, 165-167, and 1997; Stephens/ Winkler 1995, 95-100; and López Martínez 1998, 133-134. Bastianini 2010 provides a new edition and commentary of fragment D. Studies on loci paralleli, vocabulary, prosody and linguistic and stylistic aspects by Jeništová 1953; Kussl 1991 and 1997; Stephens/ Winkler 1995; Morgan 1998; Gärtner 2010; López Martínez 1998 , 2010, 2019 (volume in preparation); Kanavou 2016, and Artés 2018. See also Trnka-Amrhein 2018. Regarding the provenance of P.Berol.6926, see Harrauer/Worp 1993, and for the date of this papyrus, see 2005 .
} 
Corso (2010). ${ }^{2}$ Fragments A, B and C can be dated to around the late 1st century $\mathrm{BC}$ and the early 1 st century $\mathrm{AD},{ }^{3}$ The verso of this papyrus was reused around the year $101 \mathrm{AD}$. Fragment D dates from the 1st century AD. Therefore, taking into account the material factors, the novel was probably written halfway through the 1 st century $\mathrm{BC}^{4}$

2. An ostrakon, O.Edfu 306 (henceforth fragment E) from Apollinopolis Magna and dated to around the 1 st -2 nd centuries $A D$, is probably associated with the novel. The text is very short and presents reading problems, ${ }^{5}$ but could be a scholarly text inspired by the novel's plot, as is the case with $O . B o d l .2175$, which provides evidence of the scholarly use of the novel of Parthenope. ${ }^{6}$

3. There are also mosaics, dated to between the late 2 nd century and early 3rd century AD, with images probably based on scenes from Ninus. These were found in the Roman province of Syria, in two villae in nearby towns (Alexandretta, now Iskenderun, and Daphne, near Antioch on the Orontes), and provide iconographic evidence that the novel's theme remained popular for several centuries after it was written. They depict similar scenes from several episodes of Ninus, such as Prince Ninus sitting on a chair and gazing at a portrait which presumably shows an image of his betrothed.

4. Finally, there is a literary testimony, also from the province of Syria and more specifically from a city located near Antioch and Alexandretta, called Samosata - where Lucian was born around 125 AD. The writer quotes Ninus and Metiochus, the main characters of another lost Greek

\footnotetext{
${ }^{2}$ Cavallo 2005 and Del Corso 2010. See also general conclusions about dating reused papyri in Lama 1991 and Houston 2009.

${ }^{3}$ According to Wilcken 1893, 164 and 190: "Wenn ich somit die Mitte des 1. Jhs. n. Chr. als spätesten terminus ante quem für die Herstellung der Handschrift bezeichnen möchte, will ich damit nicht sagen, dass sie nicht bedeutend älter sein könne, vielleicht noch aus der letzten Ptolemäerzeit stamme [...]. Leichter fügen sich die Momente unter der Annahme zusammen, dass er vor Chr. Geb. entstanden ist."

${ }^{4}$ Regarding other recent proposals about the origin and chronology of the first novels, see Bowie 2002; Tilg 2010 and Laplace 2011.

${ }^{5}$ Stramaglia 1996, 151-153 and López Martínez 1998 , 68-69.

${ }^{6}$ Editions and commentaries of the lost novel Parthenope: Stephens/Winkler 1995, 72-100; López Martínez 1998, 121-44 and Hägg/Utas 2003. See also Kussl 1991, 165-7; López Martínez/Ruiz-Montero $2016^{\mathrm{a}}$ and $2016^{\mathrm{b}}$.

${ }^{7}$ In relation to these mosaics, see Quet, 1992, who provides the previous bibliography. See also Newby 2007. See infra, section V.
} 
novel. Ninus, Metiochus and Achilles are characters of rhetorical declamations in theatres (Lucian, Pseudol. 25). ${ }^{8}$

\section{The context of the novel's creation}

The novel's plot takes place in the region of Mesopotamia, where the audience between the 1st century BC and the 1st century AD was sufficiently educated to read a Greek text written in a literary register. ${ }^{9}$ The present study provides a new perspective on the origin of this novel, and possibly on the origin of the genre itself as a whole, insofar as Ninus was most probably one of the first novels - and maybe even the first - in the European literary tradition.

The region of Mesopotamia became profoundly Hellenised following Alexander's conquests, ${ }^{10}$ a time that encompassed consolidation of the singular Parthian period in the mid 2nd century BC. In the year 141 BC, Mithridates I of Parthia established the Arsacid dynasty in a multi-ethnic state, the centre of which was the city of Seleucia-on-Tigris. Mithridates called himself 'pro-Greek' and minted coins in Greek, and the Parthians spoke Greek and generally showed a tolerant attitude towards other civilisations, but especially towards the Greeks, with whose culture they became imbued. ${ }^{11}$

\footnotetext{
${ }^{8}$ Stramaglia 1996, 151-153.

${ }^{9}$ Greek papyri and parchments have been found at archaeological sites such as $\mathrm{Ai}$ Khanoum, Dura Europos and Avroman. With regard to the documents from Avroman, see Minns 1915 and MacKenzie 1987. For Dura Europos, see Kilpatrick 1964 and Crisci 1996. The bibliography on the materials from Ai Khanoum is so extensive that I cannot mention all the published titles here. The series Fouilles d'Ai Khanoum has been published since 1973. See also Bernard 1967; Rapin/Hadot/Cavallo 1987; Lemer 2003; Clarysse/Thompson 2007; and Bernard 2012, among others. Attention should also be paid to the editions of the Greek inscriptions from the Greek Far-East by Canali de Rossi 2004 and those from Iran and Central Asia by $2012^{a}$, in collaboration with Bernard.

${ }^{10}$ On the concepts of 'Hellenisation', 'Hellenising' and 'being Hellenised', see Mairs 2012 and Geiger 2014. Regarding the Syrian and/or Assyrian identity of Greek authors, see a recent synthesis by Andrade 2013 and 2014.

${ }^{11}$ Apollodorus Artemita wrote the Parthica around the year $100 \mathrm{BC}$. This work, of which only some fragments have survived to the present day, is the first history of the Parthians in the Greek language. Apollodorus embodies the idea of patriotism, which is why his historiographic work implies a reaffirmation of Parthian nationalism in the Greek language: see Alonso-Núñez 1989. The Parthica served as a reference for Strabo and Gnaeus Pompeius Trogus, who authored the Historiae Philippicae, written in Latin ca.
} 
The epicentre for the creation of Ninus was a particularly rich and culturally complex context: the banks of the Tigris River, where a group of Greek language speakers who probably constituted a cultured, educated elite in the paideia lived during the 1 st century $\mathrm{BC} .^{12}$ Its readers would have belonged to a community of pepaideumenoi who inhabited a territory regarded as barbarian from a 'Hellenocentric' point of view. ${ }^{13}$

It therefore seems reasonable to attribute a certain feeling of pride to this circle, as well as the need to defend their origins and uphold their unique identity (they were of Greek origin, but also Persians) against other local powers and, of course, the threat represented by Rome. ${ }^{14}$

The Parthians zealously protected a territory which the Romans were unable to conquer for a long time. Within this context, as pointed out in López Martínez $2017^{\mathrm{a}}$ and $2017^{\mathrm{b}}$, Ninus might have served as a subtle kind of propaganda, using arguments similar to those already adduced by Braun in relation to the patriotism of The Life of Alexander or The Novel of Sesonchosis. ${ }^{15}$ The Assyrian king was also a native hero who cham-

I BC - I AD; see Alonso-Núñez 1987. Another interesting figure in this context is Isidorus of Charax, the author of the Mansiones Parthicae - $\Sigma \tau \alpha \theta \mu o$ I П $\alpha \rho \theta \kappa o$ í the exact date of which remains unknown, although it is usually dated to the late 1 st century $\mathrm{BC}-$ early 1 st century AD; see Chaumont 1984 and Schuol 2000. Since scholars have published extensively on the Parthians in recent years, I will only mention the introduction by Sarkhosh/Stewart 2007 and the three-volume edition of the group of sources by Hackl/ Jacobs/Weber 2010. A number of specialised journals such as Parthica or Anabasis and portals such as Abstracta Iranica, Hellenistic Far East Bibliography or Parthian Sources Online, among others, also deserve mention.

${ }^{12}$ To gain an idea of the cultural and artistic atmosphere in these cities, see Hollis 2011; Francfort/Grenet/Lecuyot/Lyonnet/Martinez-Sève/Rapin (eds.) 2014; Kaizer 2016; Wallace 2016 and Mairs 2014 and $2016^{\mathrm{b}}$, among others.

${ }^{13}$ I am using here the concept of 'implicit reader', as proposed by Wolfgang Iser, Der implizite Leser. Kommunikationsformen des Romans von Bunyan bis Beckett, 1972, within the framework of reception aesthetics. On the vagueness of the expression "hellénocentrique' used by Rougemont $2012^{\circ}, 18, \mathrm{n} .74$.

${ }^{14}$ See Schlude/Rubin, 2017, among others. Mairs $2016^{\mathrm{a}}$ has made a recent contribution to the debate on the use of Greek by the imperial or colonial powers and local elites in the Graeco-Bactrian kingdom.

${ }^{15}$ Braun 1987. We currently have five fragments from the lost novel Sesonchosis, three of which are collected in the editions by Stephens/Winkler 1995, 246-66 and LópezMartínez 1998', 357-75 (P.Oxy. 1826, P.Oxy. 2466, and P.Oxy. 3319). Trnka-Amrhein 2016 has edited two new fragments: P.Oxy. 5262 and 5263. Regarding The Alexander Romance, only the edition by Kroll 1926 and the studies by Jouanno 2002, Stoneman/ Erickson/Netton 2012 and Nawotka, 2017 will be mentioned here. 
pioned the legendary past of his people and whose condition as a native leader legitimated his authority over the territory he ruled.

According to most authors, Ninus is a mythical figure. Numerous early sources mention the episode of the wedding between Ninus and Semira-

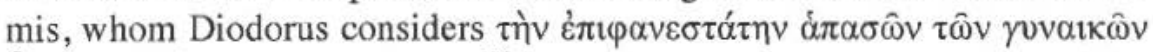

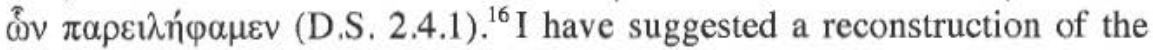
origin of this Greek legend based on the historical Assyrian, King TukultiNinurta I (1243-1207), transformed into an emblematic figure, ${ }^{17}$ and taking Malaise's classic study on the Egyptian Sesostris as her point of departure. ${ }^{18}$ The figure of Ninus probably paralleled that of the Egyptian Pharaoh Sesostris, Queen Semiramis herself and Alexander, creating a native legend using episodes and features that corresponded to various historical Assyrian kings and the historical Tukulti-Ninurta I (1243-1207) and enriching the story with elements from both the oral and the written tradition. It is in this context that the seal of King Sennacherib can be placed, which offers a historical testimony of how an Assyrian king expressed his love to his wife. ${ }^{19}$ Evidence exists of the fact that the Epic of Tukulti-Ninurta, the epic poem written during the monarch's life to commemorate his victory against Kastiliaš of Babylon, continued to be used for educational purposes during the 1 st millennium. ${ }^{20}$ Later on, classical authors such as Herodotus and Ctesias reconstructed a biography of Ninos based on a native model. Finally, Diodorus Siculus and the anonymous author of the lost novel would have composed their texts in the 1st century

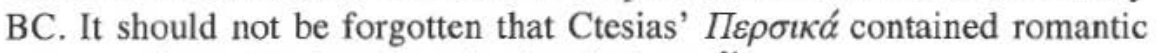
episodes that might be categorised as fictional. ${ }^{21}$

${ }^{16}$ A large number of ancient sources mention Ninus and Semiramis, separately or together as a couple, by means of which the legend has gradually been enriched and transformed throughout history and up to the present day, leaving a trail of literary and iconographic testimonies in different languages and in geographical contexts situated far from one another. It would be impossible to list them all here. A selection could include: Wagner 1902; Weidner 1936; Lenschau 1940; Roscher 1965; Lehmann-Haupt 1965; Eilers 1971; Pettinato 1985; Capomacchia 1986; Kussl 1991, 84-95 and 1997; Mignona 2000, 322-326; Novotny 2002; Rollinger 2010, 383-386 and Dalley 2013, among others.

${ }^{17}$ See López Martínez $2017^{\circ}$ and $2017^{\circ}$. Regarding the use of the term 'emblematic' in relation to Ninus, see Lens Tuero/García González/Campos Daroca 1995, 318.

${ }^{18}$ Malaise 1966.

${ }^{19}$ Radner 2012.

${ }^{20}$ See Machinist 1978 and 2014; Foster $2005^{3}$.

${ }^{21}$ Regarding Ctesias, see the translation by Llewellyn-Jones and Obson 2010; the edition by Lenfant 2004; and the proceedings by Wiesehöfer/Rollinger/Lanfranchi 2011. 
It has repeatedly been claimed that the legend of Semiramis might be based on a historical figure, ${ }^{22}$ and several contemporary inscriptions record that Sammu-ra mat was present on the battlefield and refer to her reputation in life and her titles. Semiramis became an archetype of queens married to kings from exotic and faraway lands; hence, the Hellenised form of her name $-\Sigma \varepsilon \mu i ́ p \alpha \mu 1 \varsigma$ - was applied to other highly prestigious historical Assyrian queens, such as Naqi'a-Zakuûtu. ${ }^{23}$

The political use of the figures of Ninus and Semiramis spread throughout other provinces of the Empire in a strategy that deployed a variety of formats, although primarily iconographic and numismatic ones. Thus, the main characters of this novel are depicted as the founding heroes in several cities in Asia Minor, although the clearest example of this are the reliefs decorating the Basilica of Aphrodisias, a city located in Caria, which have been dated to $90 \mathrm{AD} .^{24}$ Aphrodisias likewise received the names of

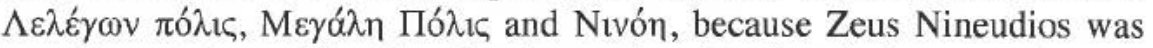
worshipped there. Worship also focused on Semiramis because she was descended from Aphrodite. Furthermore, in Aninetta, on the border between Caria and Lidia, coins were minted during the 2 nd and 3 rd centuries $\mathrm{AD}$ which portrayed Ninus as the founder of the city. ${ }^{25}$ The same occurred a little further to the north, in Lidia, in the city of Thyatira, where the figure of Semiramis appears on coins as غ̇ Lidia and Caria therefore reveal an intention of dating the origin of several cities which lacked noble ancestors to remote periods, to times on the border between myth and history. In the case of Aphrodisias, political intentions were probably combined with economic interests, since this iconographic strategy would help justify the privileged treatment that the city received from Rome. $^{26}$

${ }^{22}$ See supra, n. 17 , especially Rollinger 2008 .

${ }^{23}$ Dalley 2005 and 2013; and Lanfranchi 2011, 208: "In questo caso, dunque, si deve pensare all'accettazione da parte di Ctesia di una tradizione sulla regina assira Sammuramat già abbondantemente consolidata nel periodo a lui precedente, e derivante in sostanza dall'elaborazione di notizie provenienti dall'ambito siro-ittita e levantino. Nè Erodoto nè Ctesia, quindi, attingono in questo caso a fonti genuinamente assire, ma ricevono e sviluppano un elemento narrativo sull'impero assiro che era stato con tutta probabilità eleborato nelle sue periferie in età arcaica."

${ }^{24}$ The images of the reliefs are published in Chaniotis 2009, 315 (fig. 2a and c) and Yildirim 2004, 45 (III.1), and 51 (3 and 5).

${ }^{25}$ Robert 1980, 323-337.

${ }^{26}$ Yildirim 2004 and Chaniotis 2009. 


\section{Date of writing and profile of the author}

Palaeographical data suggest that the novel was written before the end of the 1st century $\mathrm{BC}{ }^{27}$ Gärtner studied the text of fragment $\mathrm{A}$ of the novel, concluding that it had served as a model for the episode of the wedding between Achilles and Deidamia in book I of Publius Papinius Statius' Achilleid. ${ }^{28}$ This poem must have been written between the years 94 and 96 and was left unfinished upon its author's death.

In addition, a crucial episode for the Parthians took place in $53 \mathrm{BC}$. As a result of the agreements reached between 69 and 66 BC, the Euphrates River was designated the border between Parthia and Rome. However, Crassus, the Roman appointed to rule the province of Syria, broke these agreements, causing a conflict in which Rome suffered one of its most infamous defeats. Having rejected the offer of assistance from the Armenian King Artavasdes II, Crassus led a well-equipped and numerous Roman army into battle near the strategic city of Carrhae, only to suffer a humiliating defeat at the hands of the much less numerous Parthians. In retaliation for the assistance offered to the Romans, the Parthian King Orodes II invaded and subdued Armenia. This episode is particularly relevant because the attack on the Armenians by Orodes II may have served as the inspiration for the episode of the attack on Armenia by the Assyrian Ninus described in fragment B of the Berlin Papyrus. If this were the case, $53 \mathrm{BC}$ would be the terminus post quem for when Ninus was written. ${ }^{29}$

The author of the novel may have been a Graecised individual who possessed an excellent command of the Greek language, had received the literary training of a pepaideumenos and lived on the periphery of the Greek world in the mid 1st century BC. Furthermore, based on the infor-

\footnotetext{
${ }^{27}$ See supra, section II.

${ }^{28}$ Gärtner 2010.
}

${ }^{29} \mathrm{~A}$ bit later, around the year $20 \mathrm{BC}$, the Senate presented Augustus with a marble statue. On the breastplate of the statue there was a scene in which, according to the most common interpretation, the subjected Parthian king was returning Crassus' standard to an armoured Roman. The scene of the breastplate prompts the question of when the Roman triumphalism which had inspired the creation of the statue - with a clearly propagandistic intention - became incompatible with the expression of patriotic feelings by the Parthians as manifested a few decades earlier as a result of their victory at Carrhae. Perhaps by 20 BC (the most widely accepted dating of this statue) Rome's enemies no longer displayed such pronounced nationalism. In that case, the date of $20 \mathrm{BC}$ might work as a terminus ante quem with regard to when the novel was written, although it seems audacious to suggest such a possibility. 
mation provided by the author of Callirhoe in the novel's sphragis, Xapi-

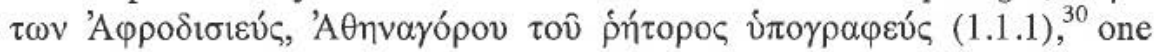
might even posit a professional with an administrative position. However, caution should be exercised when assessing such statements by the early authors, since these may have distorted the information in order to manipulate or even amuse their readers. ${ }^{31}$

\section{V.Plot of the first part of the novel}

A war episode occurs in the text of fragment $B$ and perhaps of fragment $C$. The Assyrian army, formed by native Assyrians, Greeks and Carians, fought against the Armenian enemy. Fragment A narrates a palace scene involving four members of the royal family: the two lovers and their future mothers-in-law, who are sisters. Fragment D introduces another

${ }^{30}$ The Suda 49 quotes a certain Xenophon of Antioch, to whom we could attribute this

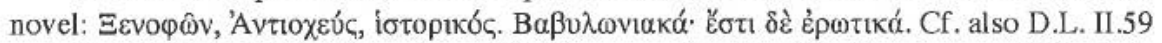
and Goulet-Cazé 1999, 265, n. 6 and 8. However, this identification is very difficult to prove at present. A good candidate would be Nicolaus Damascenus, born in Damascus in $64 \mathrm{BC}$ to an influential, Hellenised family. He received an encyclopaedic, 'Greek-style' education in which he studied rhetoric, music, sciences and philosophy, thus becoming a

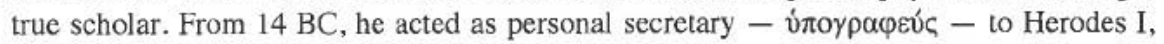
serving as his right-hand man and the tutor of his children. He wrote historical works, biographies, tragedies and even comedies. Only some of this vast corpus is known to us. For example, the Suda 393 refers to the $\Delta \rho \hat{\alpha} \mu \alpha \tau$ ๆ̂c $\Sigma \omega c c \alpha v i \delta$ oc, which is one of his lost works that recounts how Ninus offered his own daughter Susana to Ones in return for Semiramis, revealing the Damascene author's interest in this legendary saga, cf. Stronk 2010, 76. Two other facts support this identification: first, Nicolaus and Chariton both

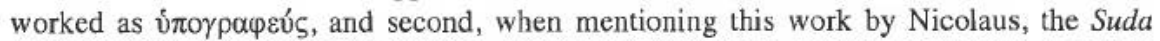
refers to $\delta \rho \hat{\alpha} \mu \alpha$, just as the Byzantine Photius - dramatikon - does to refer to Antonius

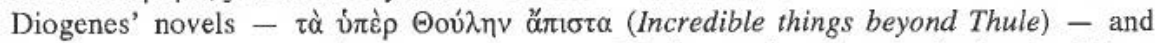
Iamblichus' B $\alpha \beta \nu \lambda \omega v i \alpha \kappa \alpha$ (Babylonian Tales). It is interesting the contribution by Geiger 2014, 11-56. Regardless, the subject of novelists' names deserves in-depth investigation due to the curious coincidences between them and certain anthroponyms of figures who were important in the cultural tradition: Xenophon of Ephesus necessarily refers back to the historian Xenophon of Athens; the author of Phoinikiká shares his name with a renowned sophist called Lollianus; a suspicious Dictys of Crete claims to be the author of an Ephemeris or Diary of the Trojan War; and even the name of the educated Iamblichus, who wrote the Babyloniaká, reminds us of the intrepid Iambulus. All of this clearly suggests that some of these novelists were probably using pseudonyms, which raises one last question: could the authors hiding behind some of these pseudonyms be women?

${ }^{31}$ See Ni Mheallaigh 2010, among others. 
change of scenario: the action moves to a beach in remote Kolchis, where Ninus, together with his crew and a woman - who does not seem to be his young betrothed of $\mathrm{B}-$ have just landed.

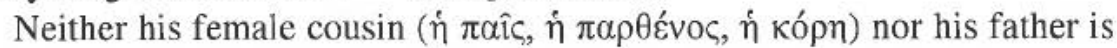
named in the papyri. This may be due to chance or might reflect the author's desire to focus all attention in this part of the action on the young prince. ${ }^{32}$ However, his mother is called $\Theta \alpha \dot{\alpha} \mu \beta \eta$ and his mother-in-law $\Delta \varepsilon \rho-$

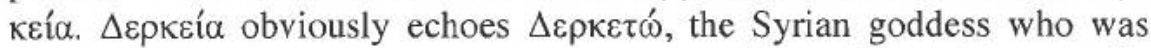
Semiramis' mother in the myth and with whom the majority of the novel's readers, familiar with any of the versions of the legend circulating at the time, would have identified Ninus' future mother-in-law..$^{33}$ These readers would also most probably identify Semiramis as the young female partner of Ninus appearing in the papyri. ${ }^{34}$

The present proposal for the novel's plot adopts the BA order of the longest fragments. ${ }^{35}$ The action narrated in fragment $\mathrm{B}$ occurs during Ninus' father's lifetime (his father is mentioned, albeit not by name, in B.II.3). There may equally be external arguments linked to the content of the text that can be read on the verso of the papyrus. ${ }^{36}$

The young Assyrian prince is raised in the palace in the company of his father and his mother, Thambe. This clearly resembles the probable beginning of Parthenope, according to the evidence supplied by the Persian ver-

${ }^{32}$ López Martínez $2017^{\mathrm{a}}$ and $2017^{\mathrm{b}}$ has tried to provide a gender-based explanation for this anonymity.

${ }^{33}$ Regarding the Syrian goddess, see Lightfoot 2003.

${ }^{34}$ See the forthcoming study by L6pez Martínez on the names in this novel.

${ }^{35}$ López Martínez 1998. Wilcken 1893, 164-165 remains undecided about the sequence of the fragments: "Erhalten sind uns zwei Fragmente, ich nenne sie A und B. A ist wiederum aus zwei Fragmenten zusammengefügt, deren eines ich unter den Urkunden fand."

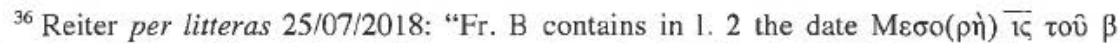

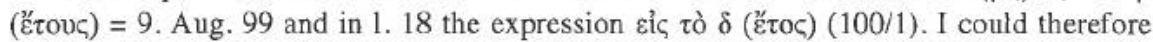
imagine that most part of this fragment was written in the third year, with a reference to a lemma from the end of the preceding second year and with one reference to the following fourth year. Fr. A contains according to Wilcken an account from Pauni of the third year

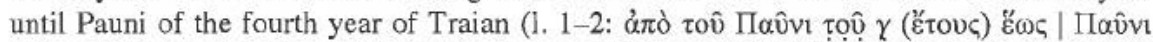

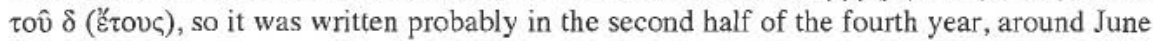
$101 \mathrm{CE}$.

As the papyrus roll has been turned round horizontally for writing on the verso, the sequence of the parts of the account on the verso should be the same as on the recto. So I think it slightly more probable that Fr. B preceded Fr. A on both sides." 
sion. ${ }^{37}$ Just like Parthenope, trained in both martial and bookish arts, Ninus receives a careful and comprehensive education throughout his childhood and adolescence.

Even as a child, he has a very close relationship with his cousin, as well as with his aunt Derkia. Achilles Tatius' main characters (1.3.6) are cousins. The most obvious model would be book I of Xenophon's Cyropaedia: Cyrus also married his cousin, Ciaxares' daughter, whom he had known since he was a child (8.5.17-18). When the young cousins reach adolescence, they discover their mutual attraction.

According to the papyrus, Ninus gradually adopts an increasingly active

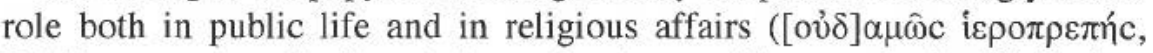
B.I.5), as expected of an heir to the throne. The novels by Xenophon (I.2.2-I.2.9) and Heliodorus (I.1-I.2) include similar religious scenes at the beginning of their respective first books. ${ }^{38}$ While one of these ceremonies is being celebrated, Ninus is surprised by some news and runs to look for his cousin. He probably finds her in the company of her (or his) mo-

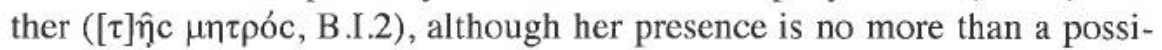
bility since mention of the mother does not prove anything, but it is supported by a number of parallels in other novels. For example, in Achilles Tatius' second book, Leucippa's mother, frightened by a bad dream, enters at the very moment when Clitophon is about to lie in bed next to his beloved (II.10.1-5), who is still a virgin in this encounter. The meeting

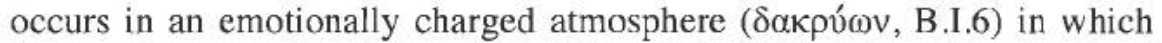

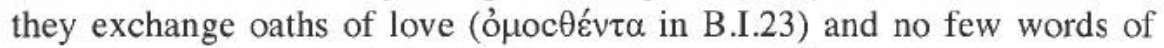
reproach (B.I.5-24). Similarly, in Chariton, an intimate encounter takes place in the midst of high emotional stress because of Chaereas' jealousy. Like Ninus, Chaereas also loses his composure: he hits his wife, who falls unconscious (1.4.10-5.2). Ninus asks his cousin to trust him and they reconcile ( $\pi \alpha v \eta \dot{\mu} \mu[$ [ o $1 c .8] \dot{\alpha} \lambda \lambda \eta \hat{\eta} \lambda$ otc, B.I.25-26). Heliodorus likewise tells us in his fifth book that Theagenes and Chariklea have a passionate encounter in a cave before being married (V.4.3-5.3). Their pleasant coexistence is suddenly interrupted when some disturbing news about the Armenians arrives at the palace (Ap $\mu \varepsilon v$ [, B.I.35). Despite starting to become involved in military affairs, Ninus still follows his father's advice, and the lovers are thus separated because Ninus must accompany or

\footnotetext{
${ }^{37}$ All the testimonies of Parthenope have been compiled by Hägg/Utas 2003. See supra,

${ }^{38}$ Also Achilles Tatius in his second book (II.12.1-2).
} note 5 . 


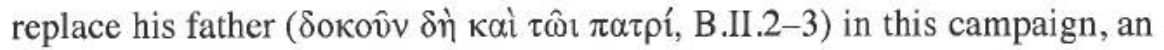
aspect which is not mentioned by Diodorus.

His first military experience is a land campaign. He organises his troops and the author very clearly emphasises that Greeks and Carians are not only allies but also part of the "hard core" of Ninus' army, together with the native Assyrians. They reach Armenia by land with an infantry, cavalry and elephants too (B.II.1-9). Because of the ice, they find it difficult to cross the mountain passes and rivers before reaching a plain where Ninus sets up camp (B.II.9-III.30). After ten days, he again organises his troops to commence the attack but not without previously making a compelling speech at the military camp aimed at raising their morale (B.III.30-38 and possibly C).

In the next fragment (A), Ninus has already reached the age of 17 and is impatient to marry his betrothed (A.I). Now, once again at home, he needs to deploy all his rhetorical skills to deliver a convincing speech to his aunt Derkia, which has been exhaustively studied due to its quality and literary interest: ${ }^{39}$ His main point is that his cousin's youth should not present an obstacle to marriage (A.I.38-A.IV.13): the same feelings overwhelm the girl, but her modesty prevents her from speaking (A.IV.20-A.V.36). The sisters meet and most probably give their consent to the wedding (A.V. 36-38).

Later on (fragment D), Ninus undertakes a naval expedition to Kolchis during which he does not seem to be accompanied by his wife or betrothed (it is uncertain whether he is already married because other novels provide us with examples in which the protagonists travel separately despite being already married, but also with others where they are apparently still unmarried). Unlike his previous expedition by land, this one will be by sea. The voyage takes Ninus and his crew to the eastern edge of

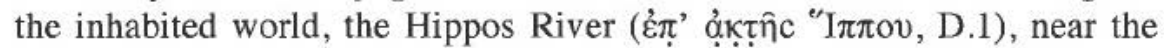
Phasis, the limit of the known world. It is unnecessary to comment on the rich tradition in Greek literature regarding this destination or the fact that,

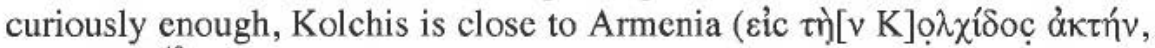
D.12-13). ${ }^{40} \mathrm{~A}$ previously captured woman also travels on board who is

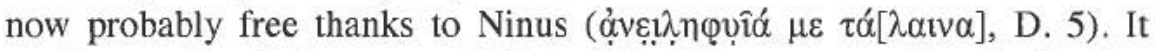
merits mention that papyrus P.Oxy. 435, 6-7, corresponding to Parthe-

\footnotetext{
${ }^{39}$ See supra, n. 1 .

${ }^{40}$ See Braund 2002.
} 
nope ${ }^{41}$ depicts an important character in the scene as $\varphi v ́ \lambda \alpha \xi-\tau \hat{c}$ c $\Pi \alpha \rho \theta \varepsilon$ -

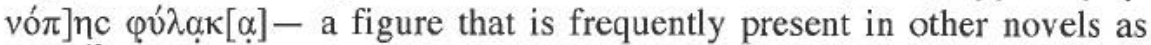
well. ${ }^{42}$ It remains unclear whether it is Ninus or another who is speaking, but the speaker addresses the woman as: $\pi \varepsilon \rho t c \pi o v ́ \delta \alpha c \tau \varepsilon$ yóval $\mu$, "Oh much desired lady!" (D.2-3). The ship becomes stranded on sandbanks

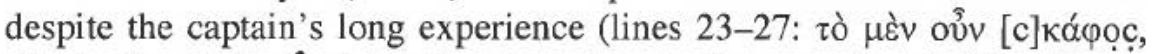

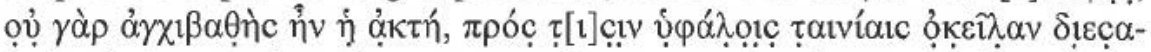
$\lambda \varepsilon v \varepsilon^{\varepsilon} \tau$ ), introducing the castaway theme, another important literary topos. ${ }^{43} \mathrm{~A}$ despondent crew leaves the ship trying to save all their belongings (D.30-35), and Ninus feels even more desperate than his fellow travellers (D.35-43). The shipwreck takes place near a locus amoenus where a forest provides shade and a spring gives fresh water (D.17-23): a similar scene can be found in Xenophon (II.11.10-11).

The landing in Kolchis casts Apollonius Rhodius' Argonautica as a key intertext of the episode. There is also a prose testimony in Latin that is contemporary with this novel, the Historiae Philippicae, written ca. 2 BC2 AD by Cnaeus Pompeius Trogus, who probably took as his reference the Parthica, written by the Greek Apollodorus Artemita in Parthia itself one century earlier. ${ }^{44}$ Although the original text of Trogus' Historiae Philippicae has been lost, some of the Epitoma by Justinus has survived, in which the history of the Parthian empire is related in books XLI and XLII. When narrating the reign of Mithridates II (XLII.2.3) and the war between the Parthians and the Armenians, ${ }^{45}$ Trogus introduces an excursus to recount the history of the Armenians from their origins. It is at this point that the work records that the first king's name was Armenius and that he had accompanied the Thessalian Jason and the Argonauts on their expedition to Kolchis. This information supplied by Trogus/Justinus constitutes a prose testimony of the same cartography -Mesopotamia-Armenia-Kolchis - presented in the novel and on a date close to that when the latter was written.

The information transmitted by the papyri ends here, rendering it difficult to reconstruct the rest of the novel. What might have happened to his

\footnotetext{
${ }^{41}$ See López-Ruiz 2016 ${ }^{\mathrm{b}}$.

${ }^{42}$ Xen. Cyr. 6.3.14; Char. 5.8.9 and 8.3.10. Regarding Parthenope, see supra, n. 5.

${ }^{43}$ On the subject of the storm and the shipwreck, see Börstinghaus 2010, 70-75.

${ }^{44}$ We know about the Parthica thanks to a small number of fragments and a citation by Athenaeus. See supra, Section III, n. 9.

${ }^{45} 121-91 \mathrm{BC}$. On the complicated chronology associated with the Parthian kings who lived during this period known as the "Dark Age" of the Arsacid dynasty, see Assar 2006.
} 
cousin? Is she waiting at home like Penelope? Is she also travelling and having adventures and mishaps on her own? $?^{46}$ Two main possibilities arise: (a) the female protagonist does not reappear until the end of the novel. This is what happens, for example, in Apollonius; or (b) both lovers follow parallel paths until they meet again in a happy ending typical of this novel.

Several testimonies may be related to an episode where the lovers' separation has taken place. There are the two famous mosaics mentioned earlier, which show the figure of Ninus alone, ${ }^{47}$ sitting on a chair and gazing at a portrait which presumably depicts his betrothed. In the one in Alexandretta, Ninus' name appears written on his head, while in that in Antioch, the prince is accompanied by a woman who apparently brings a lamp to help him gaze at the portrait of his beloved, whose image is not represented in the main scene of the mosaic but is only implied in the frame Ninus is holding in his hands. ${ }^{48}$ When the lovers have been separated in Chariton's romance, Callirhoe also gazes nostalgically at a miniature portrait of Chaereas (I.14.9-10), and the text preserved in O.Edfu 306 could also be inspired by a separation between these lovers. ${ }^{49}$

\section{Survival in the Persian tradition}

Because of its essentially oral nature, transmitted largely by minstrels, the gosan, very little is known today about the earlier corpus of Parthian legends, although it was probably very rich. However, it can be partially glimpsed in the Persian version from the pre-Islamic period:

A fragment of the Kayanian epic cycle survives in the Ayādgār $\bar{I}$ Zarērān (q.v.) or "Memorial of Zarēr". This heroic poem, transmitted in a late post-Sasanian Middle Persian version (perhaps of the 9th cen-

${ }^{46}$ Is it possible that from this point onwards, the main plot focused solely on the figure of Ninus? Would it be reasonable to posit the existence of a separate novel with Queen Semiramis as its main character? See infra, Section 9.

${ }^{47}$ Cfr. Section II, n. 6.

${ }^{48}$ It is probably a portrait of Semiramis. The woman might be a servant or the woman mentioned in fragment D or another one. Other possibilities in Stephens/Winkler 1995, 24. The images of the mosaics are published by Quet 1992, 128, fig. 2 (Iskenderum) and 130. figs. $4 \mathrm{a}$ and $4 \mathrm{~b}$ (House of the Man of Letters in Daphne). The last one is published also in Newby 2007,20 , fig. 37.

${ }^{49}$ See supra, n. 4. 
tury), is undoubtedly of Parthian origin, as evidenced by the presence of Parthian words and expressions. It relates the exploits of the Iranian hero Zarēr in the confrontation of the Iranians under King Wištāsp with King Arjāsp and his Xiyonians. A number of passages were subsequently taken over almost verbatim in the Šāh-nāma. ${ }^{50}$

Themes, characters and/or plots in Greek literature in general, and more specifically in novels such as Ninus, may have been incorporated into the wealth of Parthian oral tradition during the period when both cultures coexisted, between the 2 nd century $\mathrm{BC}$ and the 3 rd century $\mathrm{AD}^{51}$

Reports exist of Greek novels being translated into Persian, and versions of two of these are especially relevant. ${ }^{52}$ The first comprises some episodes in The Alexander Romance in the Shahnameh - The Book of Kings - by Ferdowsi (932-1021). Shahnameh is one of the most important works in Persian literature, and probably has a Parthian origin. ${ }^{53}$ The second consists of some 400 lines from the Persian verse version of Parthenope, by 'Unșuri (ca. 961-1039), the title of which refers to the main characters' names, Vãmiq u 'Adhrā (The Virgin and the Lover).$^{54}$ Other Persian poems such as Vis o Rämin by Gorgāni (11th century) and Leyli o Majnun by Nezāmi (1188) also contain elements and characteristics originating from Greek novels.

${ }^{50}$ Huyse 2006. Minorsky 1947 conducted a detailed study of the Parthian origin of Vis u Rämin.

${ }^{51}$ This also occurred in other artistic fields. Syncretism of styles was a feature of 'Parthian art' or 'Arsacid Art in Parthia.' See Downey 1986; Invernizzi 2011 and 2012 and Sinisi 2014, among others.

${ }^{52}$ Regarding the connection between Hellenistic novels and medieval Persian romances, see Davis 2002. Having confirmed the existence of Persian versions of Greek novels, it seems reasonable to suggest that some episodes in Ninus might have formed part of the corpus of Parthian legends performed by minstrels. There are three additional indications in support of this possibility: first, the fact that the protagonist is an Assyrian monarch; second, that the plot of Shahnameh revolves around the succession of Persian kings; and third and finally, that Ferdowsi's poem is of Greek origin. Confirmation of this hypothesis will eventually depend on interdisciplinary research consisting of an in-depth comparison between the Greek texts and the Persian versions in their original language. See the translations by Davis 2004 and Mohl/Lazard 1979.

${ }^{53}$ On the Persian translations of The Alexander Romance, see Stoneman/Erickson/ Netton 2012.

${ }^{54}$ On the Persian versions of Parthenope, see Hägg/Utas 2003 and 2009. See supra, n. 51 . 
Nezāmi was also the author of Kosrow o Širin, a love story involving King Kosrow and the beautiful Širin, ${ }^{55}$ and some of the episodes in this Persian romance contain motifs that can be traced back to Greek novels. For example, like Parthenope, Khosrow receives a refined education; both Shirin and Parthenope are educated and determined girls; ${ }^{56}$ Shirin falls in love with the Persian king while looking at his portrait, and the mosaics from Iskenderum and Antioch on the Orontes also contain the portrait motif ${ }^{57}$ Khosrow falls in love with Shirin when he sees her bathing naked in a pond, mirroring Chloe, who is utterly disconcerted by the sensations she experiences while watching Daphnis in the same situation (1.13.1); Shirin abruptly pushes Khosrow away when she does not want to engage in sexual intercourse, just as Ninus' betrothed does ${ }^{58}$ and - to mention yet one more example - the Persian poem includes the character of Shapour, a friend and faithful partner of Khosrow's, just as Polycharmus is of Chaireas, in Chariton's novel..$^{59}$

\section{A different novel with Semiramis as its main character?}

In Ninus, the Assyrian prince embodies the virtues shared by other leaders of ancient barbarian peoples as well as those inherent to the Greek paideia, while his betrothed is depicted in accordance with the Greek ideal of the inconspicuous wife whose silence is her best quality. ${ }^{60}$

\footnotetext{
${ }^{55}$ The name 'Shirin' could be considered a variant of 'Semiramis'. Sirin is based on a historical figure, see Scarcia, 2003, 107-26.

${ }^{56}$ In fact, Parthenope, and not Metiochos, would be the main character of this lost novel. See supra, n. 31 .

${ }^{57}$ See supra, Section II, note 6. In Chariton (I.14.9-10), it is Callirhoe who gazes at the picture of Quereas. On the theme in Antiquity of the lover gazing at a portrait, see Stramaglia 2003.

${ }_{58}$ As is reconstructed in the scene I.B. Similarly in Chariton (I.14.9-10).

59 The plot of Kosrow o Sirin has a historical backdrop, like that of Parthenope: the protagonists of the Greek novel are the daughter of Polycrates of Samos and the son of Miltiades of the Thracian Chersonesus, whereas Kosrow is the historical Sasanian King Kosrow II Parviz (590-628 CE). There was also a Coptic Christian version of the Greek novel entitled The Martyrdom of St. Parthenope. See the complete study by Hägg/Utas 2003. In this martyrology, the heroine defends her virtue as well as the Christian faith, like Sirin. Policharmus, Chaereas' friend in 4.2.2.1, among others.

${ }^{60}$ López Martínez $1998^{\mathrm{a}}$ and 2010. See supra, notes 29 and 30; Kanavou 2016 and López Martínez 2017 .
} 
However, the young girl's image in this novel does not coincide with that offered by other sources which have transmitted the legend of Semiramis. In most Greek testimonies, the Assyrian queen was descended from the Amazons and reflected the archetype of an eastern queen: beautiful, intelligent, ambitious, very powerful and with an active sexual life. ${ }^{61}$ In fact, Diodorus Siculus transforms the Assyrian queen into the protagonist of her own story in the Bibliotheca Historica. ${ }^{62}$

Moses Chorenensis brought the legend of Semiramis to Armenia in the 5 th century AD. In his History of Armenia, he tells us that when the Assyrian Queen Shamiran became King Ninus' widow, ${ }^{63}$ she fell in love with a prince called Ara the Beautiful, who was the founder of the Armenian people. Shamiran invaded Armenia to kidnap him, but Ara did not return her feelings. When he died on the battlefield, Shamiran headed south until reaching Lake Van, where she founded a city and built palaces as well as many other kinds of infrastructure. ${ }^{64}$

In addition, the name and features of the character of Širin in the previously mentioned poem by Neẓāmi seem to be inspired by Semiramis. ${ }^{65}$ Shirin is an Armenian princess with a determined character who has also received a refined education and training in physical, intellectual and artistic disciplines. Another important figure is her aunt Shamira, ${ }^{66}$ the queen of Armenia and Azerbaijan. Although further research is still pending, ${ }^{67}$ everything suggests that the two Greek traditions concerning the Assyrian queen converge in Nezāmi's Persian version: on the one hand, the 'novelistic' version embodied in the young Širin, and on the other, the mythical and historiographic one represented by the mature Shamiră.

P.Oxy. 2564 was published in 2016. There are several identification options in the editio princeps for the main character in the papyrus, a

${ }^{61}$ See supra Note 18. Some sources refer to Semiramis' contra naturam feelings: the attraction for her horse and the relationship with her own son. See supra, note 15 and Mignona 2000, among others.

${ }^{62}$ Practically contemporary with the novelist -1 st century BC. Diodorus himself compiles other versions of the legend in the form of rumours (D.S. II.20.3-5).

${ }^{63}$ History of Armenia I.16. See the translations by Mahé/Mahé 1993 and Thomson 2006.

${ }^{64}$ It is the king of Urartu, Arame or Uramu, ca. 880-840 BC and coeval with Sammu-ra mat, whose name is mentioned several times in the inscriptions of Salmanasar III. See Maciuszak 2011,87.

${ }^{\text {as }}$ Kosrow o Širin. See supra, section VI, p. 11.

${ }^{66}$ Depending on the version, her name is also given as Mehin Bãnu.

${ }^{67}$ See supra, n. 52. 
queen who conquers Egypt and builds pyramids, the principal of which is Semiramis. ${ }^{68}$ Should this hypothesis be confirmed, it would suggest that this is the fragment of a lost novel, the main character of which would be the Assyrian queen, most probably the inspiration for the character of Shamiran both in the Armenian version by Moses and the Persian one written by Neẓāmi. ${ }^{69}$

\section{Conclusions}

1. The Parthians were not only tolerant of other cultures but even adopted an open and permeable attitude towards them, especially Greek culture.

2. An unknown author of Parthian origin (who obviously spoke Greek) or of Greek origin but with close ties in Parthia, and with a considerable knowledge of Greek literary culture, may have written Ninus.

3. Both the writer himself and his readers would have easily identified with the protagonist: a native king born in the heart of Mesopotamia but with Greek training and customs.

4. We know for certain that a corpus of Parthian legends existed, although it remains largely unknown today due to its essentially oral nature. However, there is evidence that minstrels, the gosan, played an important role in transmitting this heritage.

5. Little is known about this corpus, which was probably very rich, but parts of it have survived to the present day in Persian versions from the pre-Islamic period. One of the most important works in this tradition was the Book of the Kings (Shahnameh) by Ferdowsi.

6. We have translations of Greek novels into Persian, Arabic, Coptic and other languages, both in prose and verse, the richest example of which is the Life of Alexander. Shahnameh contains episodes inspired by this work, and versions have also survived in a number of other Eastern languages. Likewise, there is also a translation into Persian of a lost Greek novel, the original of which has only survived in some papyrus fragments found in Egypt: Parthenope, a novel which also has historical content.

\footnotetext{
${ }^{68}$ Trnka-Amrhein 2016, 41-42.

${ }^{69}$ See supra, n. 41 .
} 
7. Although there are no known testimonies in Persian of Ninus, it seems plausible to suggest that they may have existed or that Ninus might have served as a model for scenes in Persian literature, perhaps for the Shahnameh.

8. During the 1st century BC, the Parthians zealously defended a territory which the Romans found impossible to conquer. This singular context explains the propagandistic intention underlying Ninus. This same intention has also been attributed to other fictional works such as the Life of Alexander or the novel of Sesonchosis, inspired by the Egyptian Pharaoh Sesostris and also lost, but of which several papyri have been preserved.

9. In the case of the Assyrian Ninus, he champions the legendary past of his people, and as a native leader, his authority over the territory is legitimate. Ninus embodies the virtues of the great leaders of Eastern civilisations while simultaneously representing Greek education and ideals; meanwhile, his betrothed, who might be Semiramis, complies with the stereotype of the Greek wife.

10. A crucial episode occurred in $53 \mathrm{BC}$ which could represent the terminus post quem for when the novel was written: the famous battle of Carrhae. Crassus had broken the agreement reached between Romans and Parthians whereby the Euphrates River became the border between the two states. The Armenian king, Artavasdes II, offered Crassus his help in the battle, but nevertheless, the Parthians humiliated the more numerous and better equipped Romans. In retaliation for the help offered to the Romans, the Parthian king, Orodes II, invaded Armenia, an episode which probably inspired the episode in the novel of Ninus' battle against Armenia described in column B of the Berlin papyrus.

\section{Bibliography}

Alonso-Núñez 1987 = J.M. Alonso-Núñez, "An Augustan World History: The 'Historiae Philippicae' of Pompeius Trogus", Greece \& Rome 34, 56-72.

- 1989 = -, "Un historien entre deux cultures: Apollodore d'Artémita", in: M.M. Mactoux/E. Geny (eds.), Mélanges Pierre Lévêque: Anthropologie et société (Annales littéraires de l'Université de Besançon, 2), Besançon, 1-6.

Anderson 2009 = M. Anderson, "The Silence of Semiramis: Shame and Desire in the Ninus Romance and Other Greek Novels", Ancient Narrative 7, 1-27.

Andrade $2013=$ N. Andrade, Syrian Identity in the Greco-Roman World. Greek Culture in the Roman World, Cambridge. 
- $2014=-$, "Assyrians, Syrians and the Greek Language in the Late Hellenistic and Roman Imperial Periods", Journal of Near Eastern Studies 73, 299-317.

Artés Hernández 2018 = J.A. Artés Hernández, "Novela de Nino: Análisis de cláusulas métricas (Pap. Berol. 6926, PSI 1305)”, Habis 49, 143-154.

Assar 2006 = Gh.F. Assar, "A Revised Parthian Chronology of the Period 91-55 BC", Parthica 8, 55-104.

Bastianini 2010 = G. Bastianini, "PSI XIII 1305. Romanzo di Nino", in: G. Bastianini/A. Casanova (edd.), I papiri del romanzo antico. Convegno internazionale di studi, Istituto Papirologico «G. Vitelli», Firenze, 279-88.

Bastianini/Casanova $2010=\mathrm{G}$. Bastianini/A. Casanova (edd.), I papiri del romanzo antico. Convegno internazionale di studi, Istituto Papirologico «G. Vitellli», Firenze.

Bernard $1967=$ P. Bernard, "Ai Khanoum on the Oxus: A Hellenistic City in Central Asia", Proceedings of the British Academy 53, 71-95.

- 2012 = -, "Ai Khanum: a Greek Colony in Post-Alexandrian Central Asia, or How to be Greek in an Oriental Milieu”, in: J. Aruz/L. Valtz Fino (edd.), Afghanistan. Forging Civilizations along the Silk Road, New York, 42-53.

Börstinghaus $2010=$ J. Börstinghaus, Sturmfahrt und Schiffbruch - Zur lukanischen Verwendung eines literarischen Topos in Apostelgeschichte 27,1-28,6, Tübingen.

Bowie 2002 = E. Bowie, "The Chronology of the Earlier Greek Novels since B.E. Perry: Revisions and Precisions", Ancient Narrative 2, 47-63.

Boyce 1957 = M. Boyce, "The Parthian Gōsān and the Iranian Minstrel Tradition", Journal of Royal Asiatic Society, 18, 10-45.

Braun 1938 = M. Braun, History and Romance in Graeco-Oriental Literature, New York/ London 1987 (= Oxford 1938).

Braund 2002 = D. Braund, "Indian traders at Phasis: neglected texts on Ancient Georgia", in: M. Faudot/A. Fraysse/E. Geny (edd.), Pont Euxin et commerce: la genèse de la 'route de la soie'. Actes du IXe Symposium de Vani (Colchide, 1999), Besancon, 287295.

Canali de Rossi 2004 = F. Canali de Rossi, Iscrizioni dello estremo oriente greco. Un repertorio, Bonn 2004.

Capomacchia 1986 = M.G. Capomacchia, Semiramis: una femminilità ribaltata, Roma 1986.

Carr $2011=$ D.M., Carr, The Formation of the Hebrew Bible: A New Reconstruction, Oxford, 312 .

Cavallo 2005 = G. Cavallo, "Veicoli materiali della letteratura di consumo. Maniere di scrivere e maniere di leggere", in: G. Cavallo, Il calamo e il papiro. La scrittura greca dall'età ellenistica ai primi secoli di Bisanzio (Pap.Flor. XXXVI), Firenze, 216, 222 (= O. Pecere/A. Stramaglia (edd.), La letteratura di consumo nel mondo greco-latino. Atti del Convegno Internazionale. Cassino, 14-17 settembre 1994, Cassino 1996, 15, 21).

Chaniotis 2009 = A. Chaniotis, "Myths and Contexts in Aphrodisias", in: U. Dill/ C. Walde (edd.), Antike Mythen: Medien, Transformationen und Konstruktionen, Berlin, 313-338.

Chaumont 1984 = M.L. Chaumont, "Études d'histoire parthe, V. La route royale des Parthes de Zeugma à Séleucie du Tigre d'après l'Itinéraire d'Isidore de Charax", Syria $61(1-2), 63-107$.

Clarysse/Thompson $2007=$ W. Clarysse/D .J. Thompson, "Two Greek Texts on Skin from Hellenistic Bactria”, Zeitschrift für Papyrologie und Epigraphik 159, 273-279. 
Crisci 1996 = E. Crisci, Scrivere greco fuori d'Egitto. Ricerche sui manoscritti grecoorientali di ori-gine non egiziana dal IV secolo a.C. all'VIII d.C., Firenze.

Dalley $2005=$ S. Dalley, "Semiramis in History and Legend: A case study in interpretation of an Assyrian historical tradition, with observations on archetypes in ancient historiography, on euhemerism before Euhemerus, and on the so-called Greek ethnographic style", in: E.S. Guen (ed.), Cultural borrowings and ethnic appropriations in antiquity, Stuttgart, 11-22.

- $2013=-$, "The Greek Novel 'Ninus and Semiramis"', in: T. Whitmarsh/S. Thomson (edd,), The Romance Between Greece and the East, Cambridge, 117-126.

Davis 2002 = D. Davis, Panthea's Children: Hellenistic Novels and Medieval Persian Romances, New York.

- $2004=-$, Stories from the Shahnameh of Ferdowsi. Vol. 3, Washington, D.C.

Del Corso 2010 = L. Del Corso, "Il Romanzo Greco a Ossirinco e suoi lettori in: G. Bastianini/A. Casanova (edd.), I papiri del romanzo antico. Convegno internazionale di studi, Istituto Papirologico G.Vitellli, Firenze, 258-259.

Dostálová $1991=\mathrm{R}$. Dostálová, 1 romanzo greco e $i$ papiri, Praha .

Downey 1986 = S.B. Downey, "Art in Iran iv. Parthian Art", Encyclopaedia Iranica II. 6, 580-585.

Eilers $1971=$ W. Eilers, Semiramis: Entstehung und Nachhall einer altorientalischen Sage, Wien.

Foster $2005^{3}=$ B.R. Foster, Before the Muses: An Anthology of Akkadian Literature, Bethesda $1993\left(=2005^{3}\right), 318-323$ and 209-230.

Francfort/Grenet/Lecuyot/Lyonnet/Martincz-Sève/Rapin $2014=$ H.P. Francfort/F. Grenet/ G. Lecuyot/B. Lyonnet/L. Martinez-Sève/C. Rapin (edd.), Il y a 50 ans... la découverte d'Aï Khanoum. 1964-1978, fouilles de la Délégation archéologique française en Afghanistan (DAFA), Paris.

Gärtner 2010 = Th. Gärtner, "Der Ninos-Roman als Vorbild für die Hochzeitshandlung im ersten Buch der Achilleis des Statius”, Hermes 138, 296-307.

Geiger 2014 = J. Geiger, Hellenism in the East: Studies on Greek Intellectuals in Palestine, Stuttgart.

Goulet-Cazé 1999 = M.O. Goulet-Cazé, Diogène Laërce. Vies et Doctrines des Philo. sophes Illustres, Paris.

Gregoratti 2016 = L. Gregoratti, "Dura-Europos: A Greek Town of the Parthian Empire", in: T. Kaizer (ed.), Religion, Society and Culture at Dura-Europos, Cambridge, 16-29.

Hackl/Jacobs/Weber $2010=$ U. Hackl/B. Jacobs/D. Weber (edd.), Quellen zur Geschichte des Partherreiches. Textsammlung mit Úbersetzungen und Kommentaren, 3 vols., Göttingen.

Hägg/Utas, $2003=$ T. Hägg/B. Utas, The Virgin and her Lover. Fragments of an Ancient Greek Novel and a Persian Epic Poem, Leiden/Boston.

- $2009=-$, "Eros goes East: Parthenope the Virgin Meets Vãmiq the Ardent Lover", in: I. Nilsson (ed.), Plotting with Eros: Essays on the Poetics of Love and the Erotics of Reading, Copenhagen, 153-86.

Harrauer/Worp $1993=$ H. Harrauer/K. Worp, "Literarische Papyri aus Soknopaiu Nesos", Tyche 8, 35-40.

Hollis 2011 = A. Hollis, "Greek Letters in Hellenistic Bactria", in: D. Obbink/R. Rutherford (edd.), Culture in Pieces. Essays on Ancient Texts in Honour of Peter Parsons, Oxford, $104-118$. 
Houston 2009 = G.W. Houston, "Papyrological Evidence for Book Collections and Libraries in the Roman Empire", in: W.A. Johnson/H.N. Parker (edd.), Ancient Literacies: The Culture of Reading in Greece and Rome: The Culture, Oxford, 233-267.

Huyse $2006=\mathrm{Ph}$. Huyse, "Iran viii. Persian Literature (1) Pre-Islamic", Encyclopaedia Iranica XIII.4, 410-414.

Invernizzi 2011 = A. Invernizzi, "Parthian Art - Arsacid Art", Topoi 17, 189-207.

$-2012=-$, "Remarks on the Intercultural Encounters in the Hellenized Orient", Parthica $14,89-108$.

Jeništová 1953 = R. Jeništová, "Nejestarši Román Světové Literatury", Listy filologické 76 , $30-54$.

Jouanno 2002 = C. Jouanno, Naissance et métamorphoses du Roman d'Alexandre. Domaine grec, Paris.

Kaizer $2016=$ T. Kaizer (ed.), Religion, Society and Culture at Dura-Europos (Yale Classical Studies 38), Cambridge.

Kanavou $2016=$ N. Kanavou, "The Vocabulary of Chaste Love in the Ninus Fragments", Classical Philology 111, 276-282.

Kilpatrick 1964 = G.D. Kilpatrick, "Dura-Europos: the Parchments and the Papyri", Greek, Roman, and Byzantine Studies 5, 215-225.

Kroll $1926=$ G. Kroll, Historia Alexandri Magni (Pseudo-Callisthenes). Recensio Vetusta, Berlin.

Kussl $1991=$ R. Kussl, Papyrusfragmente griechischer Romane. Ausgewählte Untersuchungen, Tübingen.

- 1997 = -, "Ninos-Roman", Papyrologica Lupiensia 5, 141-204.

Lama 1991 = M. Lama, Aspetti di tecnica libraria ad Ossirinco: copie letterarie su rotoli documentari, Aegyptus 71, 55-120.

Lanfranchi 2011 = G.B. Lanfranchi, "Gli Assyriakà di Ctesia", in: J. Wiesehöfer/R. Rollinger/G.B. Lanfranchi (edd.), Die Welt des Ktesias: Ctesias' World, Wiesbaden, 175-223.

Laplace 2011 = M.M. Laplace, "Pour la datation du roman de Chariton: la figure de Démétrios le Cynique, envers du vrai philosophe", Emerita 79, 341-356.

Lehmann-Haupt 1965 = C.F. Lehmann-Haupt, in: W.H. Roscher (ed.), Ausfiihrliches Lexikon der griechischen und römischen Mythologie, 4.1,678-702, s.v. Semiramis.

Lenfant 2004 = D. Lenfant, Ctésias de Cnide. La Perse. L'Inde. Autres fragments, Paris.

Lens Tuero/Campos Daroca $1997=\mathrm{J}$. Lens Tuero/J. Campos Daroca, "La geografía de Asia en el libro II de la Biblioteca Histórica de Diodoro de Sicilia", Emerita 65, 17-44.

Lens Tuero/García González/Campos Daroca 1995 = J. Lens Tuero/J.M. García González' F.J. Campos Daroca, Diodoro Sículo, Biblioteca histórica, Madrid.

Lenschau $1940=$ T. Lenschau, RE, 7, 1204-1212, s.v. Semiramis.

Lerner 2003 = J.D. Lerner, "The Ai Khanoum philosophical papyrus", ZPE 142, 45-51.

Lightfoot 2003 = J.L. Lightfoot, Lucian, On the Syrian Goddess, Oxford.

Llewellyn-Jones/Obson $2010=$ L. Llewellyn-Jones/J. Obson, Ctesias' History of Persia: Tales of the Orient, Londres/New York.

López Martínez 1998 = M.P. López Martínez, Fragmentos papiráceos de novela griega, Alicante.

- $1998^{\text {b }}=-$, "La paideia del príncipe Nino", in: A. López Eire, J.M. Labiano Ilundain y A. Seoane Pardo (edd.), Retorica, Política e Ideología desde la Antigüedad hasta nuestros días. Actas del II Congreso Internacional. Salamanca, noviembre 1997, Volumen I, Salamanca, 51-56. 
$-2010=-$, "New contributions to some papyri labelled as 'incerta' in a corpus of novel fragments", in: G. Bastianini/A. Casanova, I papiri del romanzo antico. Convegno internazionale di studi, Istituto Papirologico "G. Vitelli», Firenze, 95-119.

- 2017 = -, "El asirio Nino, personaje de leyenda y de novela", in: M.J. Albarrán Martínez/R. Martín Hernández/I. Pajón Leyra, Estudios Papirológicos. Textos literarios $y$ documentales del siglo IV a.C. al IV d.C., Madrid, 99-115.

$-2017^{b}=-$, "La representación del cuerpo como reflejo de intereses nacionalistas en la cultura griega antigua: a propósito de la leyenda de Nino y Semíramis", Respublica 20, $581-602$.

$-2017^{\circ}=-$, "La acción novelada de la reina Semíramis. El fragmento P.Oxy. 5264 entre algunos testimonios de su leyenda," in: C Martínez-López/P. Ubric-Rabaneda (edd.), Cartografías de género en las ciudades antiguas (Granada), Granada, 87-103.

- 2019, "Greek Personal Names, Unnamed Characters and Pseudonyms in The Ninos Novel", in: A. Nodar/S.Torallas (edd.), Proceedings of the 28th International Congress of Papyrology, Barcelona 2016 Universitat Pompeu Fabra, Barcelona, 119-128 (in preparation).

López Martínez/Ruíz Montero 2016 = M.P. López Martínez/C. Ruíz Montero, "Parthenope's Novel: P.Berol. $7927+9588+21179$ Revisited", Journal of Juristic Papyrology, $28,235-250$.

- 2016 b $^{\text {- }}$ "Parthenope's Novel: P.Oxy. 435 Revisited", in: J.G. Montes Cala/R.J. Gallé Cejudo/M. Sánchez Ortiz de Landaluce/T. Silva Sánchez (edd.), Fronteras entre el verso y la prosa en la literatura helenística y helenístico-romana, Bari, 479-489.

Machinist $1978=$ P. Machinist, The Epic of Tukulti-Ninurta I: A Study in Middle Assyrian Literature, $\mathrm{PhD}$ diss. Yale 1978 (= Ann Arbor, Mi. 1992).

- 2014 = -, "Das Tukulti-Ninurta Epos", Reallexikon der Assyriologie, 14.3-4, 180-181.

Maciuszak 2011 = C. Maciuszak, "The Mystery of Shamiran: Echoes of the Semiramis Legend in Persian Literature", Cahiers de Studia Iranica 45, 81-93.

MacKenzie 1987 = D.N. MacKenzie, "Avroman Documents", Encyclopaedia Iranica III.1, 111.

Mahé/Mahé 1993 = A. Mahé/J.-P. Mahé, Moise de Khorène. Histoire de l'Arménie, Paris.

Mairs 2012 = R. Mairs, "Hellenization", in R.S. Bagnall/K. Brodersen/C.B. Champion/A. Erskine/S.R. Huebner (edd.), The Encyclopedia of Ancient History, Oxford.

- 2014 = -, The Hellenistic Far East: Archaeology, Language and Identity in Greek Central Asia, Berkeley.

$-2016^{\mathrm{a}}=-$, "New discoveries of Documentary texts from Bactria: Political and Cultural Change, Administrative Continuity", Journal of Juristic Papyrology 28, 2037-2061.

$-2016^{\circ}=-$, "'Lapis Lazuli', Homer and the Buddha: Material and Ideological Exchange in West Asia (c. 250 BCE-200 CE)", in: Tamar Hodos (edd.), The Routledge Handbook of Archaeology and Globalization, London, 885-898.

Malaise 1966 = M. Malaise, "Sesostris, Pharaon de legende et d'histoire", CdE 41, 244-272.

Mignona 2000 = E. Mignona, "Semiramide e Nino", in A. Stramaglia (ed.), "E $\rho \omega \varsigma$. Antike trame greche d'amore, Bari, 322-326.

Minns $1915=$ E.H. Minns, "Parchments of the Parthian Period from Avroman in Kurdistan," Journal of Hellenic Studies 35, 22-65.

Minorsky 1947 = V. Minorsky, "Vīs u Rāmīn: a Parthian Romance (conclusion)", Bulletin of the School of Oriental and African Studies, University of London, 12(1), 20-35. 
Mohl/Lazard $1979=\mathrm{J}$. Mohl/G. Lazard, Le Livre des Rois, Paris.

Morgan 1998 = J.P. Morgan, "On the Fringes of the Canon: Work on the Fragments of Ancient Greek Fiction (1936-1994)", in: W. Haase (ed.), ANRW II 34.4. Berlin and New York 1998, 3330-7.

Nabel 2017 = J. Nabel, "The Seleucids Imprisoned: Arsacid-Roman Hostage Submission and its Hellenistic Precedents", in: J.M. Schlude/B.B. Rubin (edd.), Oxford, 27-28.

Nawotka $2017=$ K. Nawotka, The Alexander Romance by Ps.-Callisthenes. A Historical Commentary, Leiden.

Newby 2007 = Newby, Z., "Landscape and Identity in the Mosaics of Antioch', in: J. Roy/ C. Adams/A.G. Roy (edd.), Travel, geography and Ancient Greece, Egypt and the Near East, Oxford, 199-202.

Ni Mheallaigh $2010=\mathrm{K}$. Ni Mheallaigh, "The game of the name: onymity and the contract of reading in Lucian", in: F. Mestre/P. Gómez (edd.), Lucian of Samosata: Greek writer and Roman citizen, Barcelona, 83-94.

Novotny 2002 = J.R. Novotny, The Prosopography of the Neo-Assyrian Empire 3.1, s.V. "Sammu-ramat".

Parmentier/Barone 2011 = E. Parmentier/F.P. Barone, Nicolas de Damas. Histoires. Recueil de coutumes. Vie d'Auguste. Autobiographie, Paris.

Pettinato $1985=$ G. Pettinato, Semiranide, Milano.

Quet 1992 = M.H. Quet, "Romans grecs, mosaiques romans", in: M.F. Baslez/P. Hoffmann/M. Trédé, (edd.), Le monde du roman grec, Paris, 125-58.

Radner 2012 = K. Radner, "The seal of Tašmetum-šarrat, Sennacherib's queen, and its impressions", in: G.B. Lanfranchi/D. Morandi Bonacossi/C. Pappi/S. Ponchia, (edd.), Leggo! Studies presented to Frederick Mario Fales, Wiesbaden, 687-698.

Rapin/Hadot/Cavallo $1987=$ C. Rapin/P. Hadot/G. Cavallo, "Les textes littéraires grecs de la Trésorerie d'Ai" Khanoum", Bulletin de correspondance hellénique, 111.1, 225-266.

Robert $1980=\mathrm{L}$. Robert, $\dot{A}$ travers l'Asie Mineure: poètes et prosateurs, monnaies grecques, voyageurs et géographie, Paris.

Rollinger $2010=\mathrm{R}$. Rollinger, Reallexicon der Assyriologie und Vorderasiatischen Archäologie 12.5.6, s.v. "Semiramis".

Rougemont $2012^{\mathrm{a}}=\mathrm{G}$. Rougemont, Inscriptions grecques d'Iran et d'Asie centrale (Corpus inscriptionum Iranicarum. Part II, Inscriptions of the Seleucid and Parthian Periods and of Eastern Iran and Central Asia. 1, Inscriptions in Non-Iranian Languages I), London.

- 2012 ${ }^{b}=-$, "Les inscriptions grecques d'Iran et d'Asie centrale. Bilinguismes, interférences culturelles, colonisation", Journal des Savants, 1, 3-27.

Sarkhosh/Stewart $2007=$ C.V. Sarkhosh $/$ S. Stewart (edd.), The Age of the Parthians, London (= The Idea of Iran, vol. II).

M. Sartre, D'Alexandre à Zénobie: Histoire du Levant antique (IVe siècle av. J.-C. - IIIe siècle ap. J.-C.), Paris, 2001.

Scarcia $2003=$ G. Scarcia, Scirin : la regina dei magi, Milan .

Schlude/Rubin 2017 = J.M. Schlude/B.B. Rubin (edd.), Arsacids, Romans and Local Elites: Cross-Cultural Interactions of the Parthian Empire, Oxford/Havertown.

Schuol $2000=$ M. Schuol, Die Charakene $:$ ein mesopotamisches Königreich in helle nistisch-parthischer Zeit, Stuttgart.

Sinisi 2014 = F. Sinisi, "Sources for the history of art of the Parthian period: Arsacid coinage as evidence for continuity of imperial art in Iran", Parthica 16, 5-59. 
Stephens/Winkler 1995 = S.A. Stephens/J.J.Winkler (edd), Ancient Greek Novels. The Fragments. Introduction, Text, Translation, and Commentary, Princeton.

Stoneman/Erickson/Netton $2012=$ R. Stoneman/K. Erickson/l. Netton (edd.), Alexander Romance in Persia and the East, Eelde.

Stramaglia 1996 = A. Stramaglia, "Fra "consumo" e "impegno": usi didattici della narrativa nel mondo antico" y "Apppendice. Riedizione di OEdfu 306", in: O. Pecere/A. Stramaglia (edd.), La letteratura di consumo nel mondo greco-latino. Atti del convegno internazionale (Cassino, 14-17 settembre 1994), Cassino, 97-166

- 2003 = -, "Amori impossibili. P.Köln 250, le raccolte proginnasmatiche e la tradizione retorica dell' "amante di un ritratto", in: B.J. Schröder/J.P. Schröder (edd.), Studium declamatorium, München/Leipzig, 213-239.

Streck 2014 = M.P. Streck, Reallexikon der Assyriologie, 14.1-2, 180-181 and 14.3-4, $177-178$, s.v. "Tukulti-Ninurta I".

Stronk 2010 = J.P. Stronk, Ctesias' Persian History: Introduction, text, and translation, Düsseldorf.

Sulimani 2011 = I. Sulimani, Diodorus' Mythistory and the Pagan Mission. Historiography and Culture-heroes in the First Pentad of the Bibliotheke, Leiden/Boston.

Thomson $2006=$ R.W. Thomson, Moses Khorenatsi, History of the Armenians. New and revised edition of the 1978, Ann Arbor.

Tilg $2010=\mathrm{S}$. Tilg, Chariton of Aphrodisias and the invention of the Greek Love Novel, Oxford.

Trnka-Amrhein 2016" = Y. Trnka-Amrhein, "P.Oxy. 2562. Sesonchosis", The Oxyrhynchus Papyri, 84, London, 19-24.

$-2016^{\mathrm{b}}=-$, "P.Oxy. 2563. Sesonchosis", The Oxyrhynchus Papyri, 84, London, 25-40.

$-2016^{c}=-$, "P.Oxy. 2564. A Queen and her pyramids", The Oxyrhynchus Papyri, 84, London, 40-46.

$-2018=-$, "The fantastic four: Sesonchosis, Ninus, and The Alexander Romance", in: R. Stoneman/K. Nawotka/A. Wojciechowska (edd.), The Alexander Romance: History and Literature (Ancient Narrative Supplements 25), Groningen, 23-48.

Wagner 1902 = R. Wagner, "Ninos", in: W.H. Roscher (ed.), Ausführliches Lexikon der griechischen und römischen Mythologie, Bd. 3, Abtlg. 1, (1965 reimpr.), 369-371 s.v.

Wallace $2016=$ Sh. Wallace, "Greek Culture in Afghanistan and India: Old Evidence and New Discoveries”, Greece \& Rome 63, 205-226.

Weidner 1936 = E.F. Weidner, RE 17.1, 634-643, s.v. "Ninos (3)".

Wiesehöfer/Rollinger/Lanfranchi $2011=\mathrm{J}$. Wiesehöfer/R. Rollinger/G.B. Lanfranchi (edd.), Die Welt des Ktesias: Ctesias' World, Wiesbaden.

Wilcken 1893 = U. Wilcken, "Ein neuer griechischer Roman", Hermes 28, 161-193.

Wolfgang 1972 = I. Wolfgang, Der implizite Leser. Kommunikationsformen des Romans von Bunyan bis Beckett, München.

Wolski 1983 = J. Wolski, "Sur le "phihellénisme" des arsacides", Geríon 1, 147-156.

Yildirim $2004=$ B. Yildirim, "Identities and empire: Local mythology and the selfrepresentation of Aphrodisias", in: B.E. Borg (ed.), Paideia: The World of the Second Sophistic y Identities and empire: Local mythology and the self-representation of Aphrodisias, Berlin/Boston, 23-52.

Zanker $1988=$ P. Zanker, The Power of Images in the Age of Augustus, Ann Arbor, 85-91. 